Research Article

\title{
Analysis of the Frost-Induced Damage of Building Enclosures on the Territory of the Czech Republic
}

\author{
Jan Kočí (D), Jiří Maděra, Vojtěch Pommer, and Robert Černý iD \\ Department of Materials Engineering and Chemistry, Faculty of Civil Engineering, Czech Technical University in Prague, \\ Thákurova 7, 16629 Prague 6, Czech Republic
}

Correspondence should be addressed to Jan Kočí; jan.koci@fsv.cvut.cz

Received 14 May 2018; Accepted 30 July 2018; Published 30 September 2018

Academic Editor: Michael Aizenshtein

Copyright ( 2018 Jan Kočí et al. This is an open access article distributed under the Creative Commons Attribution License, which permits unrestricted use, distribution, and reproduction in any medium, provided the original work is properly cited.

A comprehensive analysis of environmental loads across the Czech Republic in terms of frost-induced damage is presented. Computational simulation of hygrothermal performance of eleven characteristic types of building envelopes, composed of both contemporary and historical materials, is performed at first. The exterior boundary conditions of the computational model are defined by a set of weather data characterizing the environmental conditions in the Czech Republic, which are acquired from 64 weather stations. The results of hygrothermal simulations are assessed using several specific damage functions. In this way, the basic datasets for the frost damage analysis are obtained. Their application as input parameters of a specially developed correction procedure based on elevation makes them possible to obtain a continuous coverage of the geographic area of the Czech Republic. Finally, isopleths of the supposed frost damage are drawn, depending on the envelope type, and damage maps are produced which may help the engineers to enhance the building envelope design process. The presented results indicate the necessity of paying attention to local environmental loads in the building enclosure design process and reveal both critical and favorable locations from the point of view of frost-induced damage to buildings.

\section{Introduction}

The primary objective of hygrothermal design is to ensure healthy and comfortable place for occupants, which must comply with the requirements for energy efficiency. Last but not least, a serious hygrothermal design should ensure a sufficient durability of the constructions in terms of their resistance to the environmental and climatic load [1-4]. Those loads are acting on the outer surface of the buildings, thus causing long-term damage to the construction, for example, in the form of corrosion or frost-induced damage $[5,6]$. The frost-induced damage is one of the most typical long-term damages of building enclosures in the Middle Europe. It affects most types of building enclosures and is manifested by various kinds of failures ranging from surface cracks to structural damage $[7,8]$. Given that building materials contain a wide range of pores, the damage is typically initialized when liquid water present in the pore system of the material is exposed to subzero temperatures. It is initiated through the nucleation, growth, and interaction of microcracks. These processes usually occur internally and are manifested by volume expansion during cooling $[9,10]$ and by macroscopic cracks that develop after repeated cycles of freezing and thawing. From this point of view, almost every porous building material that is exposed to the environment becomes vulnerable.

The thermal and hygric properties of construction materials are dependent on actual temperature and moisture content affecting the hygrothermal performance of the entire wall system or even the whole building [11-14]. Therefore, the frost-induced damage of building enclosures should be considered as a joint influence of two input factors. It is not only the material properties that need to be taken into account but also the boundary condition acting on the material's surface must be incorporated into the frost damage assessment procedures. Ignoring the characteristic climatic conditions of each location may lead to an incorrect selection of construction materials and enclosure design in 
terms of their durability. Moreover, building codes usually introduce constant thermal or hygric material properties, which are common for all locations and associated with standardized temperature and relative humidity conditions in the materials. The liquid moisture transport in the material is often even not considered at all. Such a definition does definitely not represent the actual operating conditions of the building enclosures. For that reason, it is quite a challenging task to properly assess the frost durability of wall assemblies in given locations. As the designers cannot rely on the traditional empirical rules and standardized methods due to the high variability of the environmental and material properties or insufficient quality of input data, more advanced techniques should be incorporated in order to assess the frost durability of building enclosures properly.

As the climate in the Middle Europe in not uniform, it is logical that even on the scale of individual countries the environmental conditions may significantly vary as well. In some countries, there can exist such localities, where local climate will not produce sufficient conditions for the frost damage to be initiated, as well as localities with so severe conditions that will induce abnormal frost load to the constructions. It should be noted that also the elevation changes over individual countries may imply various frost load levels. Therefore, some serious analyses of local regions in those countries should be performed providing basic information on the climatic loads, for example, in the form of the isopleth or contour maps.

The isopleth maps providing the engineers with design thermal conductivity for the region of Northeastern Spain was presented by Pérez-Bella at al. [15]. The authors analyzed weather stations across the investigated territory and calculated correction factors for the design thermal conductivity as a function of geographic coordinates. Similarly, the isopleth maps were used as an output of the investigation of water penetration risks in building facades in Brazil [16]. Those maps were also used for the territorial analysis of wind-driven rain and driving-rain wind pressure for several Spanish regions [17]. Territorial investigation of air pollution impact on construction materials in the Slovak Republic was presented in another research [18]. The authors of this study generated the maps of annual average surface loss of stone materials and carbon steel. In all of the abovementioned studies, the authors processed the data from sufficient number of weather stations providing reasonable data coverage allowing them to construct the isopleth maps and to draw scientific conclusions.

The main objective of this paper is to analyze the local frost loads on the territory of the Czech Republic and to provide the designers and engineers with an efficient tool displaying the critical locations in the country. To achieve that objective, 64 locations across the Czech Republic were monitored using meteorological stations and the weather data of those locations were recorded. Then, the computational analysis was involved, and the effect of weather data was investigated on different types of building enclosures using several damage functions. In this way, the basic datasets for the frost damage analysis were obtained. Finally, the isopleth maps were generated using interpolation techniques, and an additional correction procedure was applied in order to correlate the obtained results in the locations insufficiently covered by the weather data.

\section{Materials and Methods}

2.1. Climatic Data. For the investigation of the frost loads in the Czech Republic, 64 locations across the country were selected and the weather data from those locations were collected. As the different parts of the Czech Republic experience both hot summers (in the region of South Moravia) and cold winters (in the mountain regions), the selection covered both lowlands and mountains across the country. All weather data were obtained from the Czech Hydrometeorological Institute, which is the official authority for meteorology, climatology, hydrology, and air quality protection in the Czech Republic. They included hourly values of temperature, relative humidity, precipitation, wind direction, wind velocity, diffuse and direct shortwave radiation, sky longwave emission radiation, and longwave emission radiation and were provided in the form of the test reference year (TRY) [19-21]. The list of involved locations together with their elevations is shown in Table 1. The map of weather stations is depicted in Figure 1.

2.2. Studied Building Enclosures. The investigation of the local frost loads in the Czech Republic was carried out for various types of building enclosures covering both historical and contemporary wall assemblies. The loadbearing materials included autoclaved aerated concrete (AAC), concrete, ceramic brick, advanced hollow bricks, and sandstone. The contemporary building envelopes were provided with different types of thermal insulation layers based on polystyrene and mineral wool. The historical masonry did not have any thermal insulation. The exterior plasters were chosen with respect to the material composition of the envelopes, such as lime-cement plaster (LC), renovation plaster for historical masonry (RPHM), or lime-pozzolan plaster that was specially developed for the advanced hollow bricks (LPC). On the interior side of all structures, $10 \mathrm{~mm}$ thick lime-cement plaster was assumed. The list of studied building enclosures is shown in Table 2 .

2.3. Computational Simulation. All the simulations were performed under time-dependent boundary conditions using the finite element method. Computer simulations of hygrothermal performance of building envelopes listed in Table 2 were conducted for the time period of ten years using the HEMOT simulation tool (HEat and MOisture Transport), which is a preprocessing tool for the general finite element package SIFEL (SImple Finite Elements) [22]. In the simulations, a slightly modified version of Künzel's [23] mathematical model of coupled heat and moisture transport was used: 
TABLE 1: List of applied weather data.

\begin{tabular}{|c|c|c|c|}
\hline Location & Elevation (m a.s.l.) & Location & Elevation (m a.s.1.) \\
\hline 1 Bělotín & 306 & 33 Tuhaň & 160 \\
\hline 2 Bílá Třemošná & 322 & 34 Tušimice & 322 \\
\hline 3 Brod nad Dyjí & 177 & 35 Ústí nad Orlicí & 402 \\
\hline 4 Čáslav & 238 & 36 Valašské Klobouky & 405 \\
\hline 5 Červená & 748 & 37 Velké Meziříčí & 452 \\
\hline 6 České Budějovice & 395 & 38 Vír & 473 \\
\hline 7 Doksany & 158 & 39 Zbiroh & 476 \\
\hline 8 Domažlice & 458 & 40 Železná Ruda & 866 \\
\hline 9 Dukovany & 400 & 41 Brno - Tư̌any & 241 \\
\hline 10 Harrachov & 675 & 42 Hradec Králové & 230 \\
\hline 11 Heřmanův Městec & 275 & 43 Churáňov & 1118 \\
\hline 12 Holenice & 432 & 44 Karlovy Vary & 603 \\
\hline 13 Holešov & 222 & 45 Kocelovice & 519 \\
\hline 14 Cheb & 483 & 46 Kuchařovice & 334 \\
\hline 15 Ivanovice na Hané & 243 & 47 Liberec & 398 \\
\hline 16 Jindřichův Hradec & 524 & 48 Luka & 510 \\
\hline 17 Košetice & 534 & 49 Lysá Hora & 1322 \\
\hline 18 Kostelní Myslová & 569 & 50 Ostrava - Mošnov & 253 \\
\hline 19 Měděnec & 828 & 51 Praha - Ruzyně & 364 \\
\hline 20 Most & 240 & 52 Přibyslav & 533 \\
\hline 21 Nepomuk & 471 & 53 Ústí nad Labem & 375 \\
\hline 22 Olomouc & 215 & 54 Horní Bečva & 565 \\
\hline 23 Pec p. Sněžkou & 816 & 55 Úpice & 413 \\
\hline 24 Praha-Karlov & 261 & 56 Šumperk & 328 \\
\hline 25 Přerov & 210 & 57 Krušovice & 379 \\
\hline 26 Přimda & 742 & 58 Mladá Boleslav & 221 \\
\hline 27 Smolenice & 345 & 59 Filipova Huť & 1110 \\
\hline 28 Stř́ibro & 412 & 60 Bečov nad Teplou & 535 \\
\hline 29 Šerák & 1328 & 61 Hustopeče u Brna & 201 \\
\hline 30 Svratouch & 734 & 62 Kestřany & 381 \\
\hline 31 Tábor & 459 & 63 Slaný & 307 \\
\hline 32 Temelín & 500 & 64 Město Albrechtice & 498 \\
\hline
\end{tabular}

$$
\begin{aligned}
& \frac{d H}{d T} \frac{\partial T}{\partial t}=\operatorname{div}(\lambda \operatorname{grad} T)+L_{\mathrm{v}} \operatorname{div}\left[\delta_{\mathrm{p}} \operatorname{grad}\left(p_{\mathrm{v}}\right)\right] \\
& {\left[\rho_{\mathrm{w}} \frac{d w}{d p_{\mathrm{v}}}+(n-w) \frac{M}{R T}\right] \frac{\partial p_{\mathrm{v}}}{\partial t}=\operatorname{div}\left[D_{\mathrm{g}} \operatorname{grad} p_{\mathrm{v}}\right],}
\end{aligned}
$$

where $H\left(\mathrm{~J} \cdot \mathrm{m}^{-3}\right)$ is the enthalpy density, $L_{\mathrm{v}}\left(\mathrm{J} \cdot \mathrm{kg}^{-1}\right)$ is the latent heat of evaporation of water, $\lambda\left(\mathrm{W} \cdot \mathrm{m}^{-1} \cdot \mathrm{K}^{-1}\right)$ is the thermal conductivity, $T(\mathrm{~K})$ is the temperature, $\delta_{\mathrm{p}}(s)$ is the water vapor permeability defined by Fick's law, $p_{\mathrm{v}}(\mathrm{Pa})$ is the partial pressure of water vapor in the air, $\rho_{\mathrm{w}}\left(\mathrm{kg} \cdot \mathrm{m}^{-3}\right)$ is the water density, $w\left(\mathrm{~m}^{3} \cdot \mathrm{m}^{-3}\right)$ is the water content by volume, $n$ $(-)$ the porosity of the porous body, $M\left(\mathrm{~kg} \cdot \mathrm{mol}^{-1}\right)$ the molar mass of water vapor, $R\left(\mathrm{~J} \cdot \mathrm{K}^{-1} \cdot \mathrm{mol}^{-1}\right)$ is the universal gas constant, $t(s)$ denotes time, and $D_{\mathrm{g}}(s)$ is the global moisture transport function. The exact sources of hygric, thermal, and basic physical properties of building materials [24-32], which were used in the simulations as input parameters, are summarized in Table 3 in detail.

2.4. Applied Damage Functions. The hygrothermal performance of studied building envelopes listed in Table 2 was evaluated using several damage functions, which were introduced recently [32]. These damage functions allow

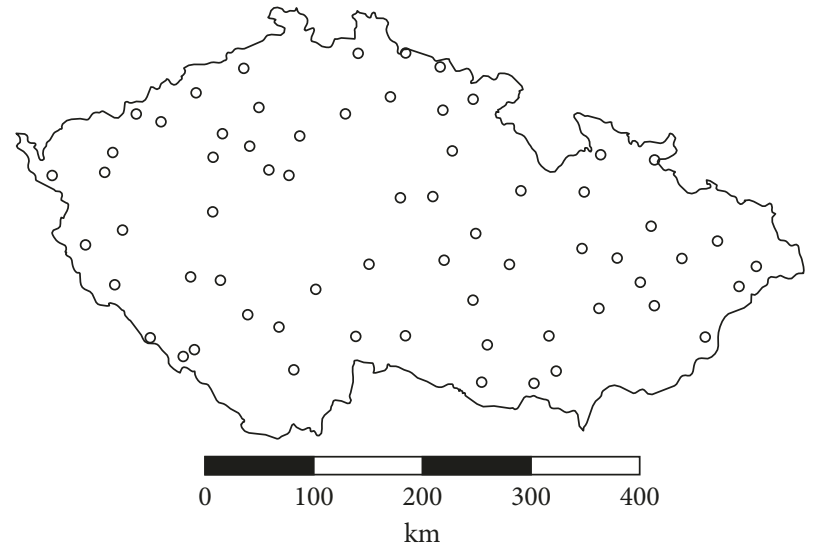

Figure 1: Map of involved weather stations in the Czech Republic.

a relative assessment of severity of environmental loads in terms of frost-induced damage. In this way, various regions of the Czech Republic and their local climatic loads can be analyzed. The applied damage functions are based on the assessment of temperature and moisture content distribution across the wall system over time with respect to pore characteristics of individual material layers. In this paper, the functions evaluate the performance in a particular point of the 
TABLE 2: List of studied building enclosures.

\begin{tabular}{lccc}
\hline Building envelopes & Load-bearing material & Thermal insulation $(100 \mathrm{~mm})$ & Plaster $(10 \mathrm{~mm})$ \\
\hline 1 & AAC $(375 \mathrm{~mm})$ & Expanded polystyrene & LC plaster \\
2 & AAC $(375 \mathrm{~mm})$ & Mineral wool & LC plaster \\
3 & Ceramic brick $(450 \mathrm{~mm})$ & N/A & LC plaster \\
4 & Ceramic brick $(450 \mathrm{~mm})$ & Expanded polystyrene & LC plaster \\
5 & Ceramic brick $(450 \mathrm{~mm})$ & Mineral wool & LC plaster \\
6 & Concrete $(300 \mathrm{~mm})$ & Expanded polystyrene & LC plaster \\
7 & Concrete $(300 \mathrm{~mm})$ & Mineral wool & LC plaster \\
8 & Advanced hollow brick $(500 \mathrm{~mm})$ & N/A & LPC plaster \\
9 & Advanced hollow brick $(500 \mathrm{~mm})$ & Expanded polystyrene & LPC plaster \\
10 & Sandstone $(800 \mathrm{~mm})$ & N/A & N/A \\
11 & Sandstone $(800 \mathrm{~mm})$ & N/A & RPHM \\
\hline
\end{tabular}

wall assembly further referred to as "Point of investigation." This point of investigation was placed $2 \mathrm{~mm}$ under the exterior surface of each studied wall. Three different damage functions were applied throughout the paper, namely, time-of-frost (TOF), amount-of-solidified-water (ASW), and number of indicative freeze/thaw cycles (IFTC). However, the assessment using abovementioned damage indexes can be further modified, so that not only one point is investigated. For example, one can investigate several selected points, and then their average can be used as the function output. The definition of damage function output should be done with respect to particular construction type and application purposes.

The mathematical description of the applied damage functions is given below. However, at first, some physical simplifications need to be introduced, in order to ensure a simple applicability of those functions and to keep their fast execution rate: (i) water primarily fills the pores from smallest to larger ones; (ii) when the hygroscopic moisture content in the investigated point is exceeded, all excess moisture is considered to be in the liquid phase; (iii) the freezing point of water depresses according to the size of largest water-filled pore; (iv) part of the water in the smallest pores remains unfrozen due to freezing point depression caused by pore curvature; and (v) all liquid water which is subjected to the water/ice phase change is solidified immediately, that is, the dynamics of ice formation is neglected.

Using the assumptions (i) and (iii), the radius of largest water-filled pore can be evaluated from the pore size distribution function when the moisture content in the investigated point is known and the freezing point depression $\Delta T_{\mathrm{f}}$ in a cylindrical pore of radius $R$ can be then expressed by the Gibbs-Thomson equation as follows:

$$
\Delta T_{\mathrm{f}}(R)=\frac{2 T_{0} \gamma_{\mathrm{sl}} \nu_{1}}{\Delta h_{\mathrm{b}} R}
$$

where $\gamma_{\mathrm{sl}}\left(\mathrm{mJ} \cdot \mathrm{m}^{-2}\right)$ is the surface-free energy (interfacial tension) of the solid/liquid interface $\left(\gamma_{\mathrm{sl}}=31.7 \pm 2.7 \mathrm{~mJ} \cdot \mathrm{m}^{-2}\right.$ [33]), $v_{1}\left(\mathrm{~cm}^{3} \cdot \mathrm{mol}^{-1}\right)$ is the molar volume of the liquid $\left(\nu_{1}=18.02 \mathrm{~cm}^{3} \cdot \mathrm{mol}^{-1}\right)$, and $\Delta h_{\mathrm{b}}\left(\mathrm{kJ} \cdot \mathrm{mol}^{-1}\right)$ is the melting enthalpy in the unconfined (bulk) state $\left(\Delta h_{\mathrm{b}}=6.01\right.$ $\left.\mathrm{kJ} \cdot \mathrm{mol}^{-1}\right)$; all quantities were taken at the bulk coexistence temperature $T_{0}\left(T_{0}=273.15 \mathrm{~K}\right)$.

The TOF damage function was inspired by the commonly used time-of-wetness damage function designed for
TABLE 3: List of sources of input parameters for computational simulation.

\begin{tabular}{lc}
\hline Material & Reference \\
\hline Ceramic brick & {$[24]$} \\
Concrete & {$[25]$} \\
Autoclaved aerated concrete & {$[26]$} \\
Advanced hollow brick & {$[14]$} \\
Sandstone & {$[27]$} \\
Mineral wool & {$[28]$} \\
Expanded polystyrene & {$[29]$} \\
Lime-cement plaster & {$[30]$} \\
Renovation plaster for historical masonry & {$[31]$} \\
Lime-pozzolan plaster & {$[30]$} \\
\hline
\end{tabular}

the analysis of corrosion-related degradation [34-36]. TOF calculates the number of hours during the year when the conditions in the investigated point of the wall cross section are favorable for ice formation, that is, the temperature is below the critical temperature while the moisture content is above the critical value. TOF ranges between 0 and 8760 and can be expressed as

$$
\mathrm{TOF}=\sum_{i=1}^{8760}\left[T_{i}<T_{\mathrm{L}} \wedge w_{i}>w_{\mathrm{L}}\right],
$$

where $T_{\mathrm{L}}$ and $w_{\mathrm{L}}$ are critical values of temperature and moisture content and $T_{i}$ and $w_{i}$ are hourly values of temperature and moisture content, respectively. Note that the summation in Equation (4) uses the iverson bracket [37], which is a notation that denotes a number that is 1 if the condition in square brackets is satisfied and 0 otherwise. TOF is calculated only when both $T_{i}<T_{\mathrm{L}}$ and $w_{i}>w_{\mathrm{L}}$. The critical values $T_{\mathrm{L}}$ and $w_{\mathrm{L}}$ are defined as

$$
\begin{aligned}
& T_{\mathrm{L}}=T_{0}-\Delta T_{\mathrm{f}}(R), \\
& w_{\mathrm{L}}=w_{\text {hyg }},
\end{aligned}
$$

where $w_{\text {hyg }}$ is the hygroscopic moisture content.

The ASW damage function returns the annual amount of liquid water retained in the investigated point that is solidified under critical temperature. ASW works with the assumption that when the temperature drops below the critical level $T_{\mathrm{L}}$, and liquid water is present in the material (i.e., $w_{i}>w_{\mathrm{L}}$ ), and only a part of that amount in the 


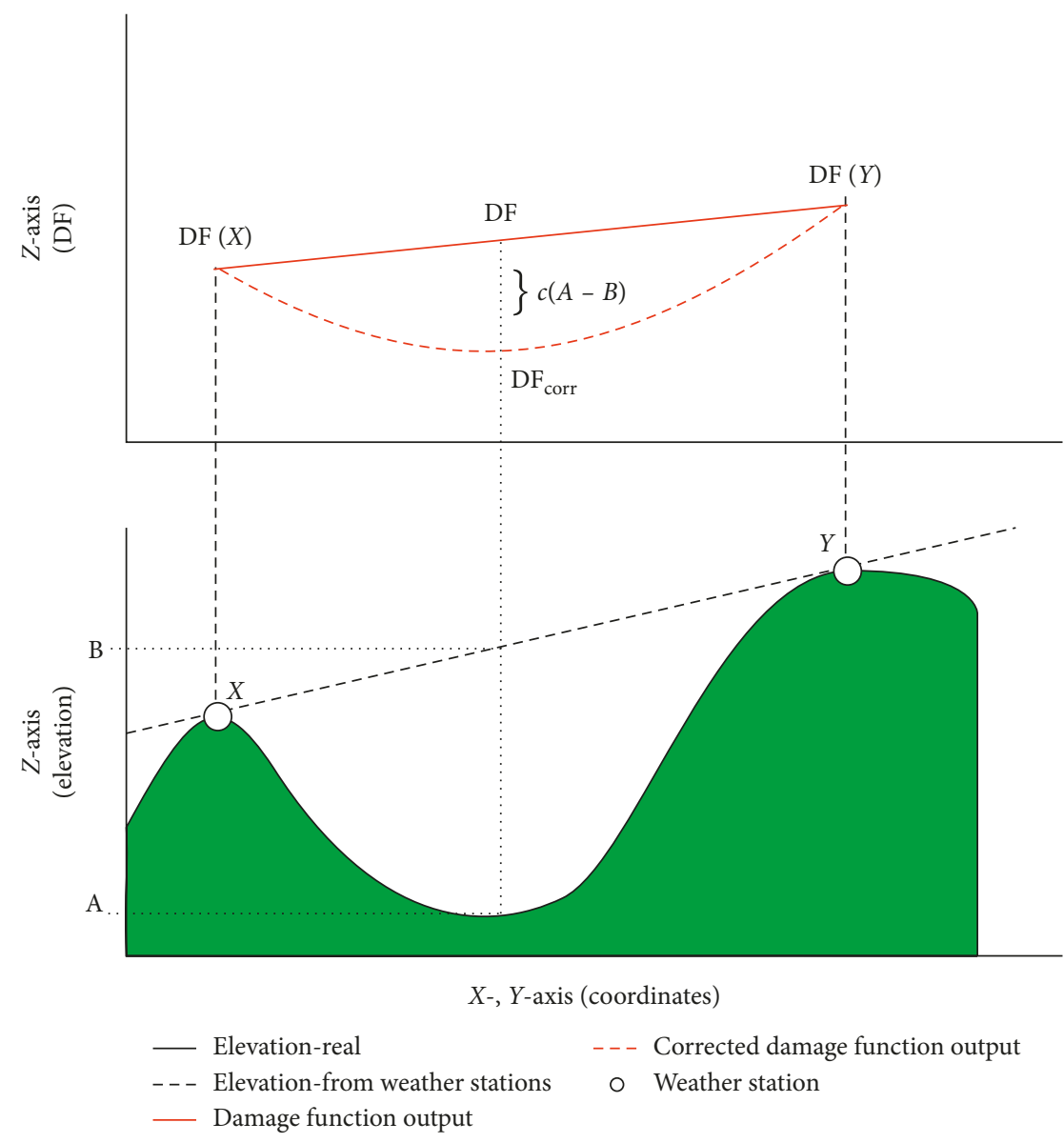

FIGURE 2: Scheme of the correction procedure.

investigated point is accounted for the ice formation. ASW can be defined as

$$
\mathrm{ASW}=\sum_{i=1}^{8760} w_{i}-w_{i, \text { unfrozen }}\left[T_{i}<T_{\mathrm{L}} \wedge w_{i}>w_{\mathrm{L}}\right]
$$

where $w_{i \text {,unfrozen }}\left(\mathrm{m}^{3} \cdot \mathrm{m}^{-3}\right)$ is the unfrozen moisture content retained in the smallest pores of the material. The unfrozen moisture content is evaluated in each calculation step in two phases. First, the critical radius $R$ is calculated reciprocally from Equation (3) from the known temperature $T_{i}$ in the investigated point. Then, the unfrozen moisture content $w_{i \text {,unfrozen }}$ is evaluated using the pore size distribution function and the known $R$ from the previous step.

The number of indicative freeze/thaw cycles (IFTC), as the last damage function, returns a hypothetical number of freeze/thaw cycles that may occur in the investigated point in the wall assembly during the simulation year. The damage function is inspired by various frost durability tests given in the national standards[38-40], where the samples are cyclically loaded by freezing and thawing for certain time periods. The standardized freeze/thaw cycle is mostly defined by 2 hours of freezing and 2 hours of thawing. Such a definition was adopted by the IFTC damage function. The critical conditions for ice formation are monitored in the point of investigation. They come from the same critical values of temperature and moisture content as in TOF or ASW (Equation (5)). In order to account the freeze/thaw cycle as valid, the freezing conditions in the point of investigation must take at least 2 hours (i.e., TOF $\geq(2)$ while any two consecutive freeze/thaw cycles must be separated by at least 2 hours of thawing period, that is, the conditions are not favorable for ice formation. If two or more freezing periods longer than 2 hours are separated by one or more periods of thawing shorter than 2 hours, it is still accounted as one freeze/thaw cycle.

2.5. Output Data Postprocessing. The computational simulations were performed for the combination of 11 wall assemblies under 4 different orientations together with 64 different sets of boundary conditions, giving 2816 output files. Each output file was analyzed by 3 different damage functions producing 8448 damage function outputs. In order to reduce this number, the outputs were first averaged by orientation and then grouped by the load-bearing material into 5 categories-AAC, ceramic brick, concrete, advance hollow clay brick, and sandstone (Table 2). All data were then processed by Surfer 14 which is an advanced tool for visualizing, mapping, and modelling in both 2D and 3D. For each set of damage function outputs consisting of 64 values with assigned $X, Y$ coordinates (weather stations), 


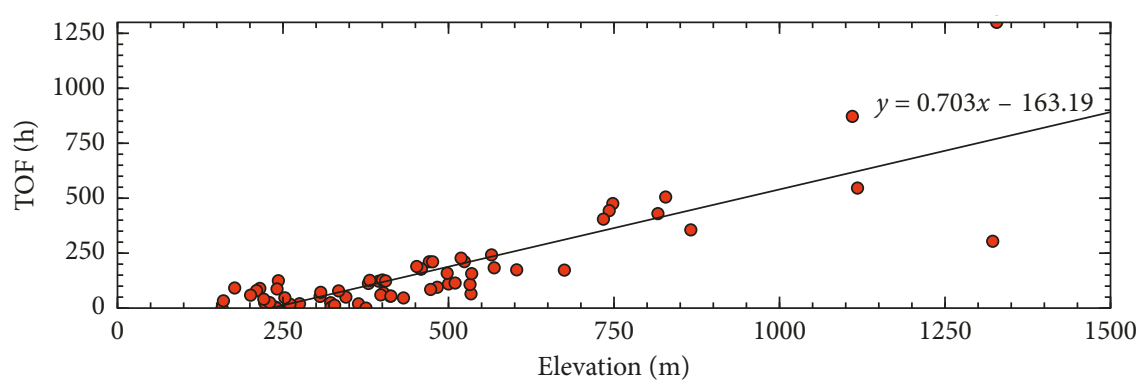

(a)

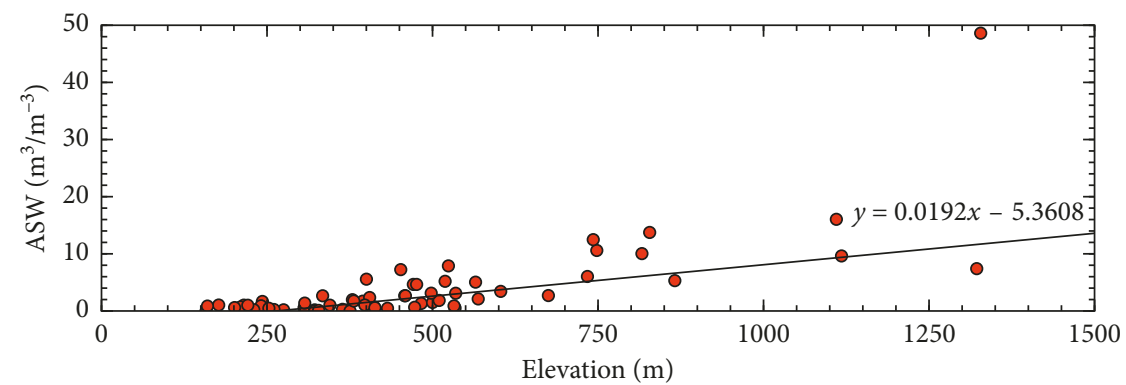

(b)

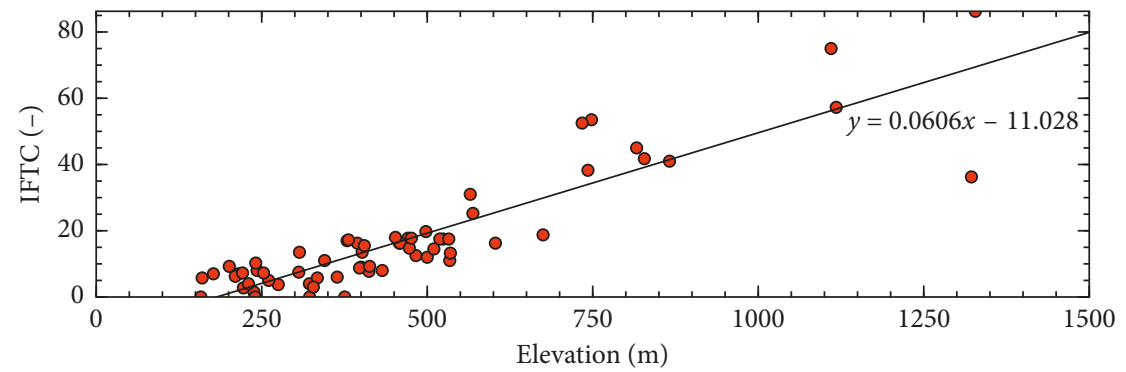

(c)

FIGURE 3: Linear regression of AAC damage function outputs plotted against elevation.

regular mesh grids were generated using the Kriging method with a linear variogram model [41]. Each grid consisted of $701 \times 301$ grid nodes providing reasonable resolution for generation of the isopleth maps.

As the total area of the Czech Republic is approximately $79000 \mathrm{~km}^{2}$, the gridding from 64 weather stations was insufficient as each weather station covers approximately the area of $1200 \mathrm{~km}^{2}$. For that reason, a correction of the generated grids was necessary to obtain satisfactory results. The correction was based on assumption that frost damage indexes correlate with the elevation. Thus, for each category of load-bearing masonry, the damage function outputs were plotted against the elevation of particular weather stations and linear regression was performed. The slope of identified linear function was then used as a correction coefficient of generated mesh grid. The values in each grid node were then corrected according to following formula:

$$
\mathrm{DF}_{\text {corr }}=\mathrm{DF}+c(A-B) \text {, }
$$

where $\mathrm{DF}_{\text {corr }}$ is the corrected value of damage function output, DF is calculated damage function output, $c$ is the
TABle 4: Correction coefficients.

\begin{tabular}{lccc}
\hline \multirow{2}{*}{ Material category } & \multicolumn{3}{c}{ Correction coefficients $c$} \\
& TOF & ASW & IFTC \\
\hline AAC & 0.7030 & 0.0192 & 0.0606 \\
Ceramic brick & 0.6314 & 0.0165 & 0.0538 \\
Concrete & 0.6721 & 0.0183 & 0.0575 \\
Hollow clay brick & 0.8036 & 0.0328 & 0.0705 \\
Sandstone & 0.4064 & 0.0110 & 0.0407 \\
\hline
\end{tabular}

correction coefficient, $A$ is the real elevation, and $B$ is the interpolated elevation from the weather station altitudes. The scheme of correction procedure is shown in Figure 2. The results of linear regression for AAC are shown in Figure 3. The correction coefficients for all group categories are summarized in Table 4 . The real elevation $A$ was obtained from publicly available data. They included all cities and villages in the Czech Republic, together with the known altitudes of all significant hilltops and mountain peaks. In total, 605 elevation data on cities and villages and 1127 elevation data on hilltop and mountain peaks were collected. 


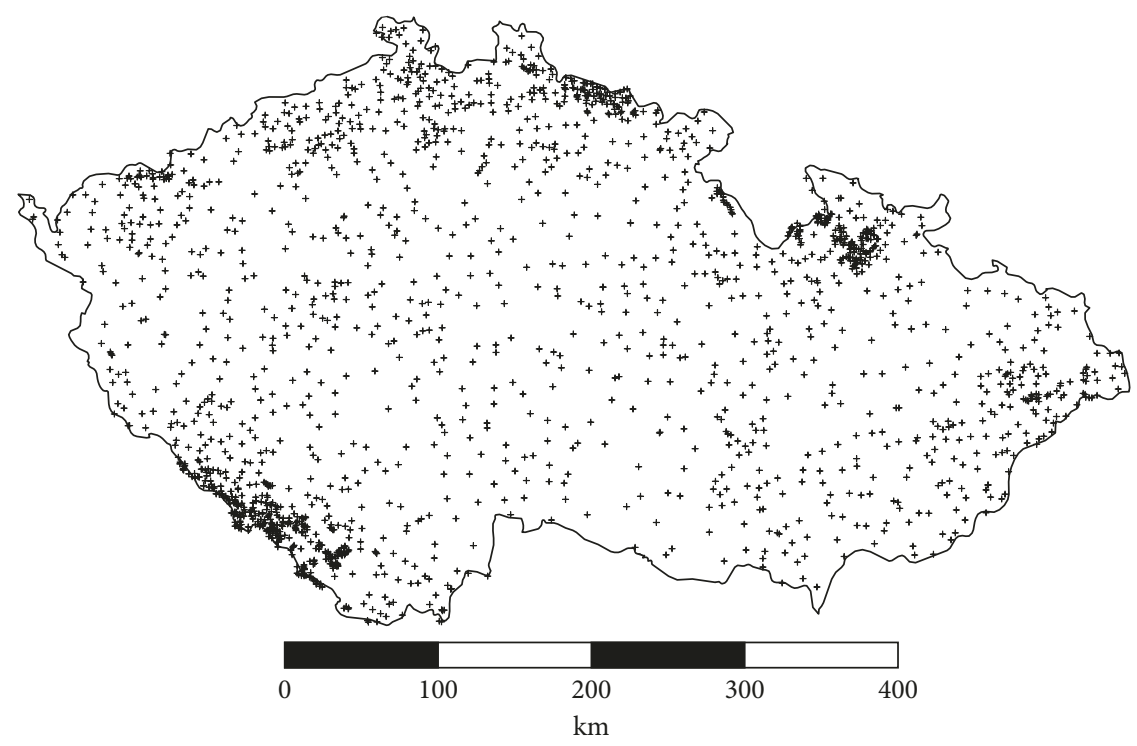

Figure 4: Publicly available control points.

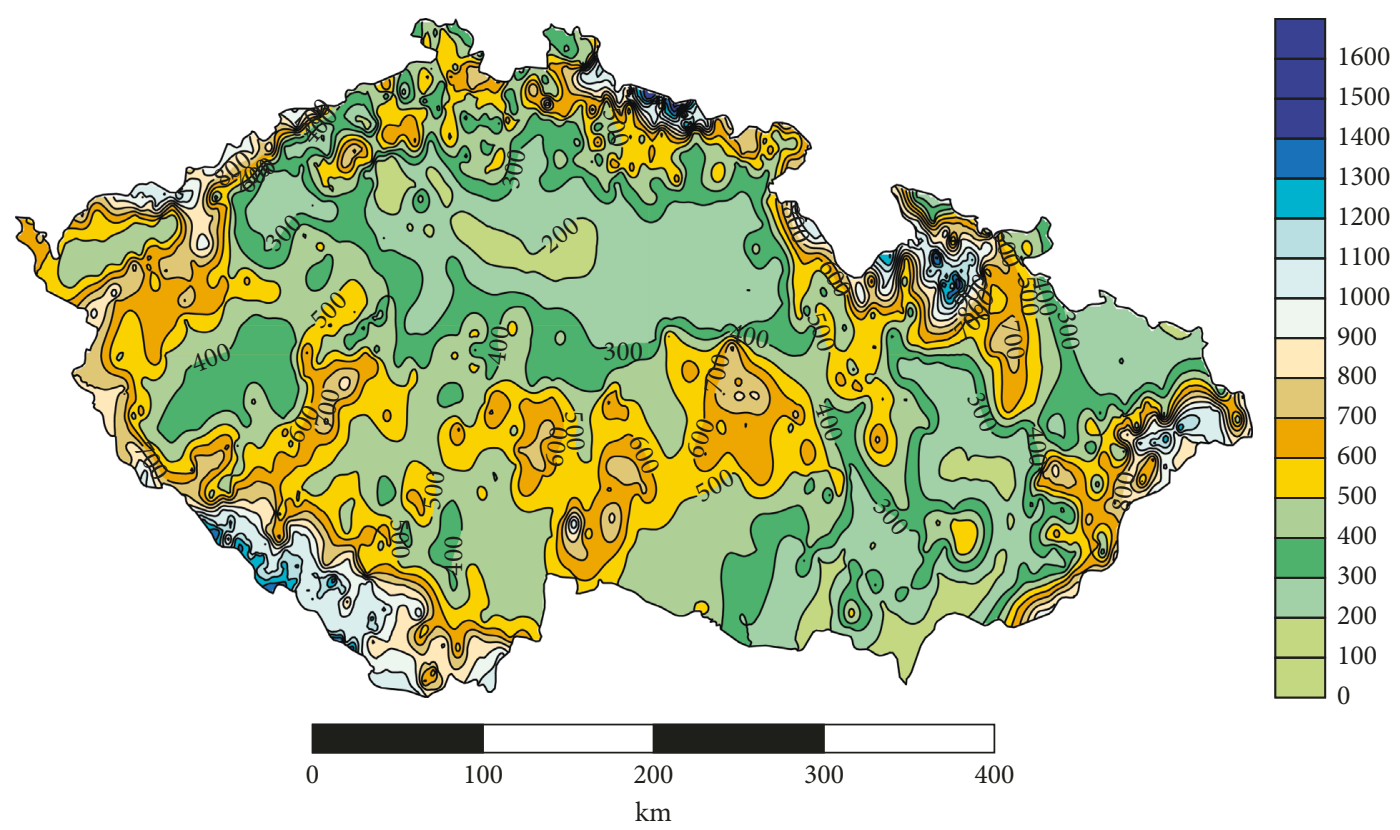

Figure 5: Elevation generated from the gathered control points.

The data were combined with the weather station elevations as well, in order to obtain zero corrections for the grid nodes representing those stations $(A-B=0)$. The map of gathered control points and generated elevation are shown in Figures 4 and 5, respectively.

\section{Results and Discussion}

The isopleth maps displaying various damage function outputs were generated to characterize the frost-induced damage in the Czech Republic, using the methods described above. In total, 15 different maps were generated but due to similar damage function outputs of AAC- and concrete-based walls, the concrete results were excluded from the figures.

The distribution of damage function outputs across the Czech Republic is shown in Figures 6-8. It is obvious that the hygrothermal performance of all studied walls correlates with each other, and the service life of surface layers is significantly affected by the material of load-bearing structure. From that point of view, the sandstone masonry proved the highest resistivity to severe environmental conditions. On the other hand, the brickwork made of advanced hollow clay brick seemed to be the most susceptible to the frost-induced damage of its surface. For example, a detailed analysis of IFTC showed that the 


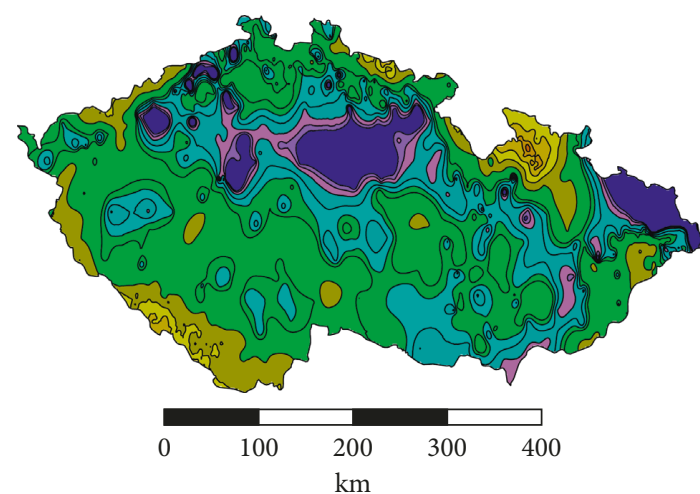

(a)

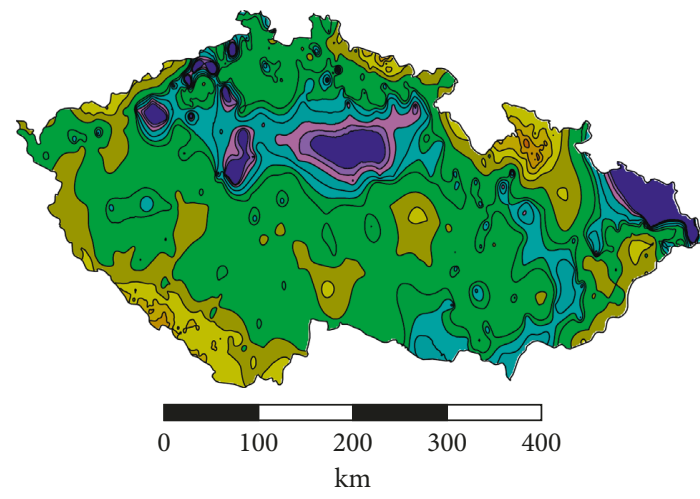

(c)
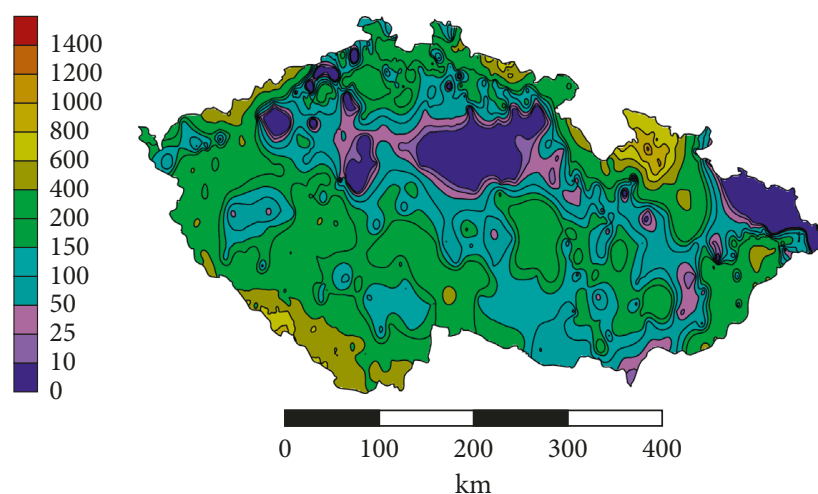

(b)

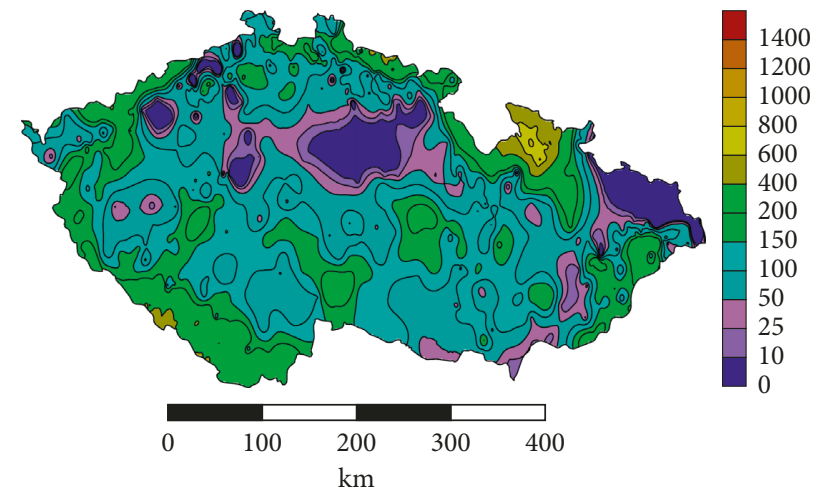

(d)

FIgURE 6: TOF outputs for (a) AAC, (b) ceramic brick, (c) hollow clay brick, and (d) sandstone masonry.

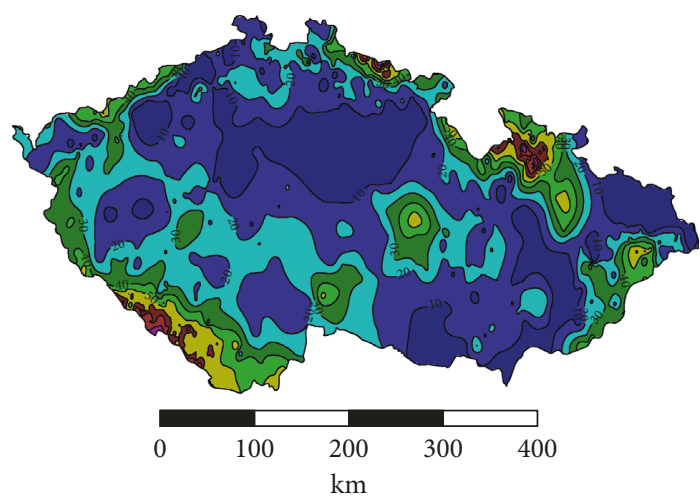

(a)

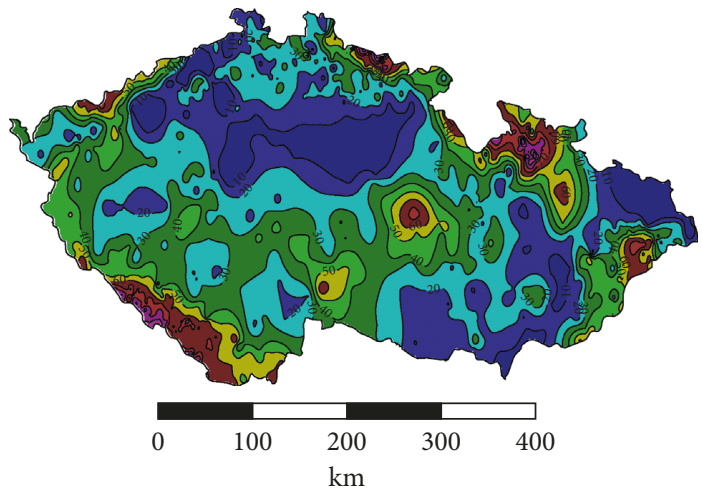

(c)

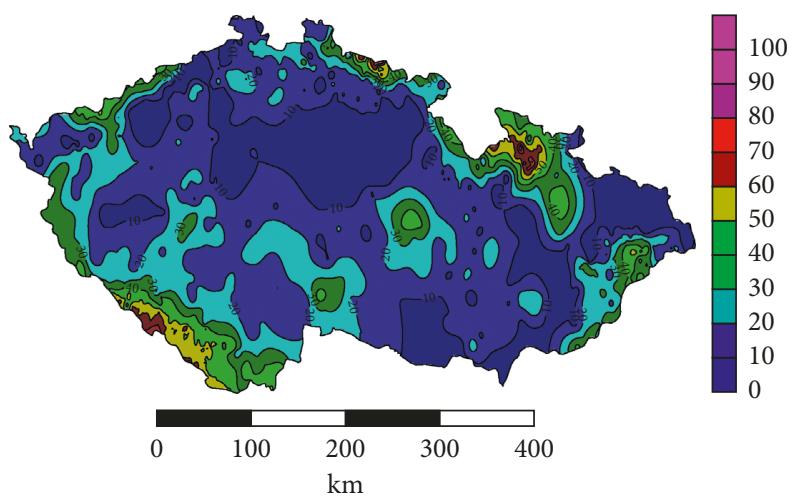

(b)

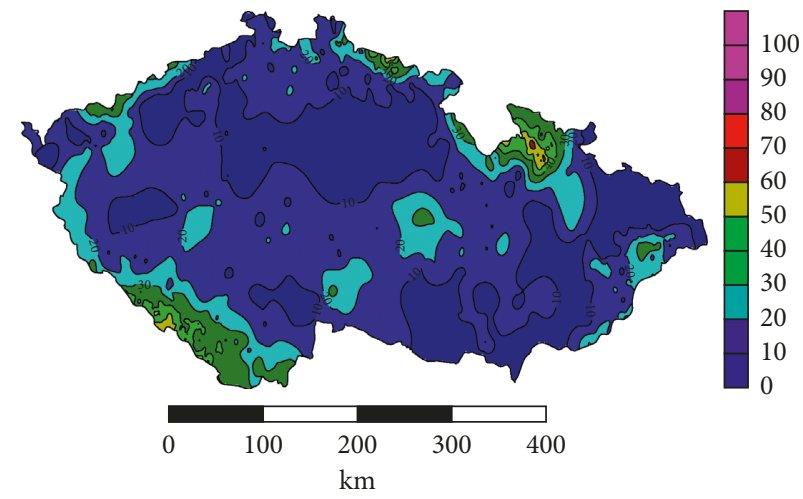

(d)

FiguRE 7: IFTC outputs for (a) AAC, (b) ceramic brick, (c) hollow clay brick, and (d) sandstone masonry. 


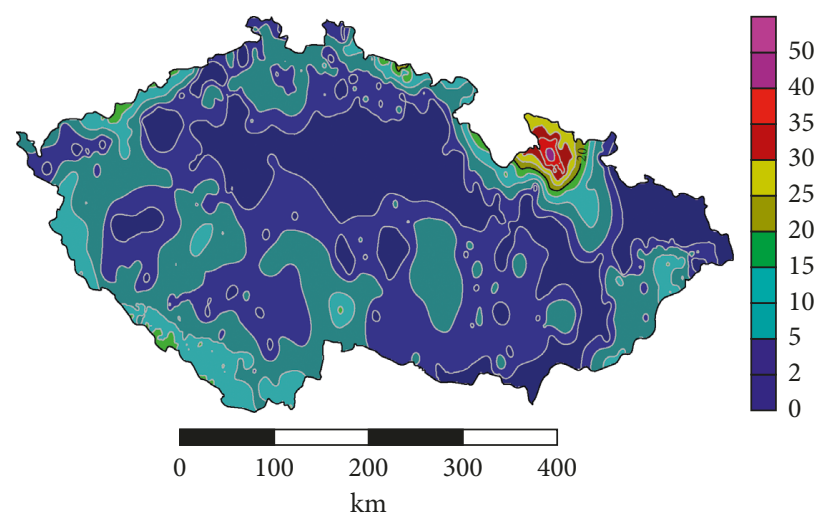

(a)

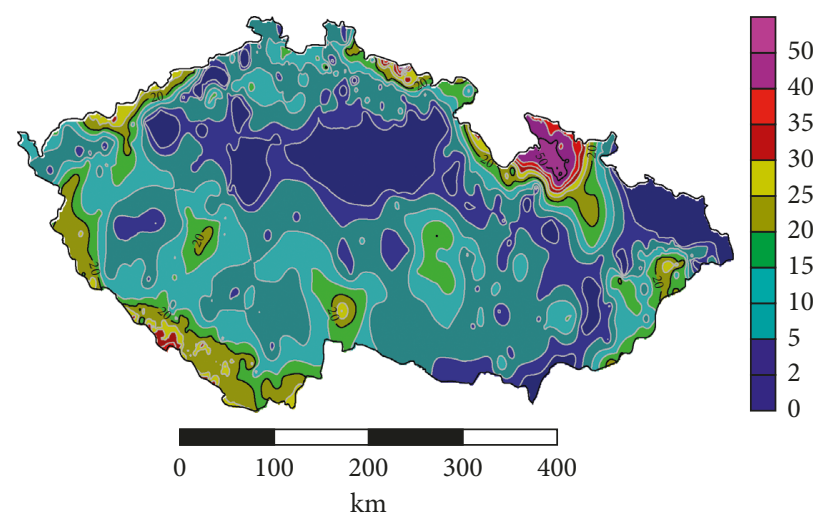

(c)

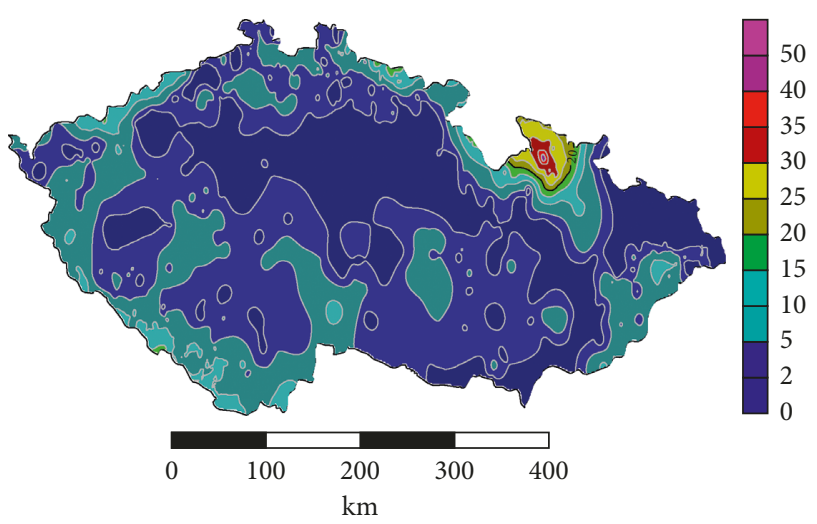

(b)

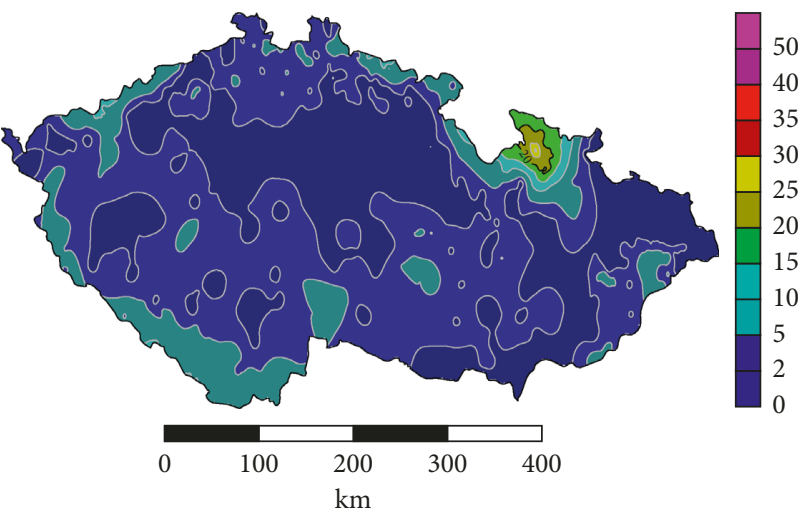

(d)

FIgURE 8: ASW outputs for (a) AAC, (b) ceramic brick, (c) hollow clay brick, and (d) sandstone masonry.

building enclosures made of advanced hollow clay bricks exhibited twice higher number of freeze/thaw cycles in surface layers than enclosures made of sandstone. For that reason, a particular attention needs to be paid to the frost damage assessment of these kinds of building walls where the choice of a proper material for exterior renders is critical.

The isopleth maps also indicated excessive frost loads in the mountain areas, which was expected. The critical areas were identified especially in Jeseníky, Šumava, and Krkonoše mountains. On the other hand, the lowest values of damage functions, that is, the mildest conditions for the frostinduced damage, were observed in the lowlands around the river Labe and in the Silesian region or South Moravia. The most severe conditions were observed in the location of Šerák in Jeseníky mountains (1328 m a.s.l.) and Filipova Hut in Šumava mountains (1110 $\mathrm{m}$ a.s.l.). The most favorable conditions were identified for the location of Ústí nad Labem (375 $\mathrm{m}$ a.s.l.) and Doksany (158 $\mathrm{m}$ a.s.l.), both located in the northern part of the Czech Republic in the valley of the Labe river.

As the applied damage functions were primarily designed for the relative assessment, that is, for a comparison of individual environmental loads, the obtained data should be confronted with field or laboratory measurements. From this point of view, the IFTC damage function seems to be the most convenient as it was designed based on standardized laboratory frost damage tests [38-40]. However, the principle of the testing methods consists in exposing fully saturated samples to alternating environment ranging from 20 to $-23^{\circ} \mathrm{C}$ for certain time period, which does not correspond well with the field conditions. Even if the freezing and thawing time periods used in IFTC calculation was adopted from the standardized procedures, the materials under field conditions become fully saturated on rare occasions only. Moreover, if the saturation occurs, it covers only minor part of the construction for a short period of time. Also, the field temperatures drop below $-20^{\circ} \mathrm{C}$ only occasionally, contrary to the standardized temperature loads. For this reason, the laboratory results of frost durability provide an incomplete information on the materials' durability. The materials loaded by real weather conditions may stand significantly higher number of freeze/thaw cycles than indicated by laboratory tests. Therefore, in future studies, it would be useful to link the damage function outputs with the results of field measurements, providing thus the designers with even more precise datasets improving the frost damage assessment.

\section{Conclusions}

A comprehensive characterization of the geographic area of the Czech Republic in terms of the frost-induced damage to building enclosures was presented in the paper. The obtained results allowed for the generation of a series of isopleth maps 
displaying the local frost loads across the country. The maps can be easily used by designers and engineers as a support in the building enclosure design.

The main findings can be summarized as follows:

(i) The service life of exterior surface layers of building enclosures was significantly affected by the material of load-bearing structure. The sandstone masonry proved the highest resistivity to severe environmental conditions, while the brickwork made of advanced hollow clay bricks was the most susceptible to the frost-induced damage of the surface.

(ii) The most severe conditions for the ice formation in building materials were observed for the mountain locations of Šerák and Filipova Huť, the mildest conditions were observed for the lowland location of Ústí nad Labem and Doksany.

(iii) The gathered data should be supplemented with the results of field measurements rather than laboratory tests, in order to enhance the applicability of the isopleth maps.

\section{Data Availability}

The data used to support the findings of this study are available from the corresponding author upon request.

\section{Conflicts of Interest}

The authors declare that they have no conflicts of interest.

\section{Acknowledgments}

This research was supported by the Czech Science Foundation under project No P105/12/G059 and by the Czech Ministry of Education, Youth and Sports under project No SGS16/199/OHK1/3T/11.

\section{References}

[1] A. Abdul Hamid and P. Wallentén, "Hygrothermal assessment of internally added thermal insulation on external brick walls in Swedish multifamily buildings," Building and Environment, vol. 123, pp. 351-362, 2017.

[2] A. Sehizadeh and H. Ge, "Impact of future climates on the durability of typical residential wall assemblies retrofitted to the PassiveHaus for the Eastern Canada region," Building and Environment, vol. 97, pp. 111-125, 2016.

[3] S. Olof Mundt-Petersen and L.-E. Harderup, "Predicting hygrothermal performance in cold roofs using a 1D transient heat and moisture calculation tool," Building and Environment, vol. 90, pp. 215-231, 2015.

[4] R. McClung, H. Ge, J. Straube, and J. Y. Wang, "Hygrothermal performance of cross-laminated timber wall assemblies with built-in moisture: field measurements and simulations," Building and Environment, vol. 71, pp. 95-110, 2014.

[5] H. Maljaee, B. Ghiassi, P. B. Lourenço, and D. V. Oliveira, "FRP-brick masonry bond degradation under hygrothermal conditions," Composite Structures, vol. 147, pp. 143-154, 2016.
[6] A. J. Lohonayi and Y. Korany, "Comparison of building enclosures designed to the minimum requirements of the 2011 NECB," Energy and Buildings, vol. 66, pp. 143-153, 2013.

[7] H. Choi, W. Zhang, and Y. Hama, "Method for determining early-age frost damage of concrete by using air-permeability index and influence of early-age frost damage on concrete durability," Construction and Building Materials, vol. 153, pp. 630-639, 2017.

[8] S. Xu, A. Li, and H. Wang, "Bond properties for deformed steel bar in frost-damaged concrete under monotonic and reversed cyclic loading," Construction and Building Materials, vol. 148, pp. 344-358, 2017.

[9] T. C. Powers and R. A. Helmuth, Proceedings, Highway Research Broad Annual Meeting, National Academy of Science, Washington, DC, USA, 1953.

[10] J. J. Beaudoin and C. MacInnis, "The mechanism of frost damage in hardened cement paste," Cement and Concrete Research, vol. 4, no. 2, pp. 139-147, 1974.

[11] F. Ochs, W. Heidemann, and H. Müller-Steinhagen, "Effective thermal conductivity of moistened insulation materials as a function of temperature," International Journal of Heat and Mass Transfer, vol. 54, no. 3-4, pp. 539-552, 2008.

[12] J. A. Clarke and P. P. Yaneske, "A rational approach to the harmonization of the thermal properties of building materials," Building and Environment, vol. 44, no. 10, pp. 20462055, 2009.

[13] S. Cai, B. Zhang, and L. Cremaschi, "Review of moisture behavior and thermal performance of polystyrene insulation in building applications," Building and Environment, vol. 123, pp. 50-65, 2017.

[14] Z. Pavlík, L. Fiala, E. Vejmelková, and R. Černý, “Application of effective media theory for determination of thermal properties of hollow bricks as a function of moisture content," International Journal of Thermophysics, vol. 34, no. 5, pp. 894-908, 2013.

[15] J. M. Peréz-Bella, J. Domínguez-Hernández, E. Cano-Suñén, M. Alonso-Martínez, and J. J. del Coz-Díaz, "Detailed territorial estimation of design thermal conductivity for façade materials in North-Eastern Spain," Energy and Buildings, vol. 102, pp. 266-276, 2015.

[16] J. Domínguez-Hernández, J. M. Peréz-Bella, M. AlonsoMartínez, E. Cano-Suñén, and J. J. del Coz-Díaz, “Assessment of water penetration risk in building facades throughout Brazil," Building Research \& Information, vol. 45, no. 5, pp. 492-507, 2017.

[17] J. M. Peréz-Bella, J. Domínguez-Hernández, E. Cano-Suñén, J. J. del Coz-Díaz, and Á. Martín-Rodríguez, "Procedure for a detailed territorial assessment of wind-driven rain and driving-rain wind pressure and its implementation to three Spanish regions," Journal of Wind Engineering \& Industrial Aerodynamics, vol. 128, pp. 76-89, 2014.

[18] M. Ivaskova, P. Kotes, and M. Brodnan, "Air pollution as an imporant factor in construction materials deterioration in Slovak Republic," Procedia Engineering, vol. 108, pp. 131-138, 2015.

[19] J. Bilbao, A. Miguel, J. A. Franco, and A. Ayuso, "Test reference year generation and evaluation methods in the continental mediterranean area," Journal of Applied Meteorology and Climatology, vol. 43, no. 2, pp. 390-400, 2004.

[20] T. Kalamees and J. Kurnitski, "Estonian test reference year for energy calculations," Proceedings of the Estonian Academy of Sciences, vol. 12, pp. 40-58, 2006.

[21] K. Lee, H. Yoo, and G. J. Levermore, "Generation of typical weather data using the ISO Test Reference Year (TRY) 
method for major cities of South Korea," Building and Environment, vol. 45, no. 4, pp. 956-963, 2010.

[22] J. Kruis, T. Koudelka, and T. Krejčí, "Efficient computer implementation of coupled hydro-thermo-mechanical analysis," Mathematics and Computers in Simulation, vol. 80, no. 8, pp. 1578-1588, 2010.

[23] H. Künzel, Simultaneous Heat and Moisture Transport in Building Components: One- and Two-dimensional Calculation Using Simple Parameters, IRB Verlag, Stuttgart, Germany, 1995.

[24] M. Čáchová, D. Koňáková, E. Vejmelková, M. Keppert, K. Polozhiy, and R. Černý, "Pore structure and thermal characteristics of clay bricks," Advanced Materials Research, vol. 982, pp. 104-107, 2014.

[25] E. Vejmelková, M. Pavlíková, M. Keppert et al., "High performance concrete with Czech metakaolin: experimental analysis of strength, toughness and durability characteristics," Construction and Building Materials, vol. 24, no. 8, pp. 1404-1411, 2010.

[26] M. Jerman, M. Keppert, J. Výborný, and R. Černý, "Hygric, thermal and durability properties of autoclaved aerated concrete," Construction and Building Materials, vol. 41, pp. 352-359, 2013.

[27] V. Kočí, J. Maděra, J. Fořt et al., "Service life assessment of historical building envelopes constructed using different types of sandstone: a computational analysis based on experimental input data," Scientific World Journal, vol. 2014, Article ID 802509, 12 pages, 2014.

[28] M. Jiřičková and R. Černý, "Effect of hydrophilic admixtures on moisture and heat transport and storage parameters of mineral wool," Construction and Building Materials, vol. 20, no. 6, pp. 425-434, 2006.

[29] M. Jerman and R. Černý, "Effect of moisture content on heat and moisture transport and storage properties of thermal insulation materials," Energy and Buildings, vol. 53, pp. 39-46, 2012.

[30] V. Kočí, J. Maděra, M. Jerman et al., “Application of waste ceramic dust as a ready-to-use replacement of cement in limecement plasters: an environmental-friendly and energyefficient solution," Clean Technologies and Environmental Policy, vol. 18, no. 6, pp. 1725-1733, 2016.

[31] E. Vejmelková, M. Keppert, Z. Keršner, P. Rovnaníková, and R. Černý, "Mechanical, fracture-mechanical, hydric, thermal, and durability properties of lime-metakaolin plasters for renovation of historical buildings," Construction and Building Materials, vol. 31, pp. 22-28, 2012.

[32] J. Kočí, J. Maděra, M. Keppert, and R. Černý, "Damage functions for the cold regions and their applications in hygrothermal simulations of different types of building structures," Cold Regions Science and Technology, vol. 135, pp. 1-7, 2017.

[33] S. Jähnert, F. V. Chávez, G. E. Schaumann, A. Schreiber, M. Schönhoff, and G. H. Findenegg, "Melting and freezing of water in cylindrical silica nanopores," Physical Chemistry Chemical Physics, vol. 10, no. 39, pp. 6039-6051, 2008.

[34] F. Corvo, T. Perez, T. Martin et al., "Time of wetness in tropical climate: considerations on the estimation of TOW according to ISO 9223 standard," Corrosion Science, vol. 50, no. 1, pp. 206-219, 2008.

[35] S. McCabe, P. Brimblecombde, B. Smith, D. McAllister, S. Srinivasan, and M. Basheer, "The use and meanings of 'time of wetness' in understanding building stone decay," Quarterly Journal of Engineering Geology and Hydrogeology, vol. 46, no. 4, pp. 469-476, 2013.
[36] J. Van den Bulcke, J. Van Acker, and J. De Smet, "An experimental set-up for real-time continuous moisture measurements of plywood exposed to outdoor climate," Building and Environment, vol. 44, no. 12, pp. 2368-2377, 2009.

[37] K. E. Iverson, A Programming Language, John Wiley and Sons, New York, NY, USA, 1962.

[38] ČSN EN 12371, Natural Stone Test Methods-Determination of Frost Resistance, Czech Office for Standards, Metrology and Testing, Praha, Czech Republic, 2010.

[39] ĆSN 72 1565-14, Testing of Brick clays: Determination of the Frost Resistance, Czech Office for Standards, Metrology and Testing, Praha, Czech Republic, 1986.

[40] ČSN 72 2452, Testing of Frost Resistance of Mortar, Czech Office for Standards, Metrology and Testing, Praha, Czech Republic, 1970.

[41] A. Gupta, T. Kamble, and D. Machiwal, "Comparison of ordinary and Bayesian kriging techniques in depicting rainfall variability in arid and semi-arid regions of north-west India, Environ," Environmental Earth Sciences, vol. 76, no. 15, 2017. 


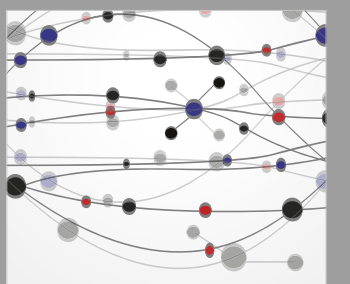

The Scientific World Journal
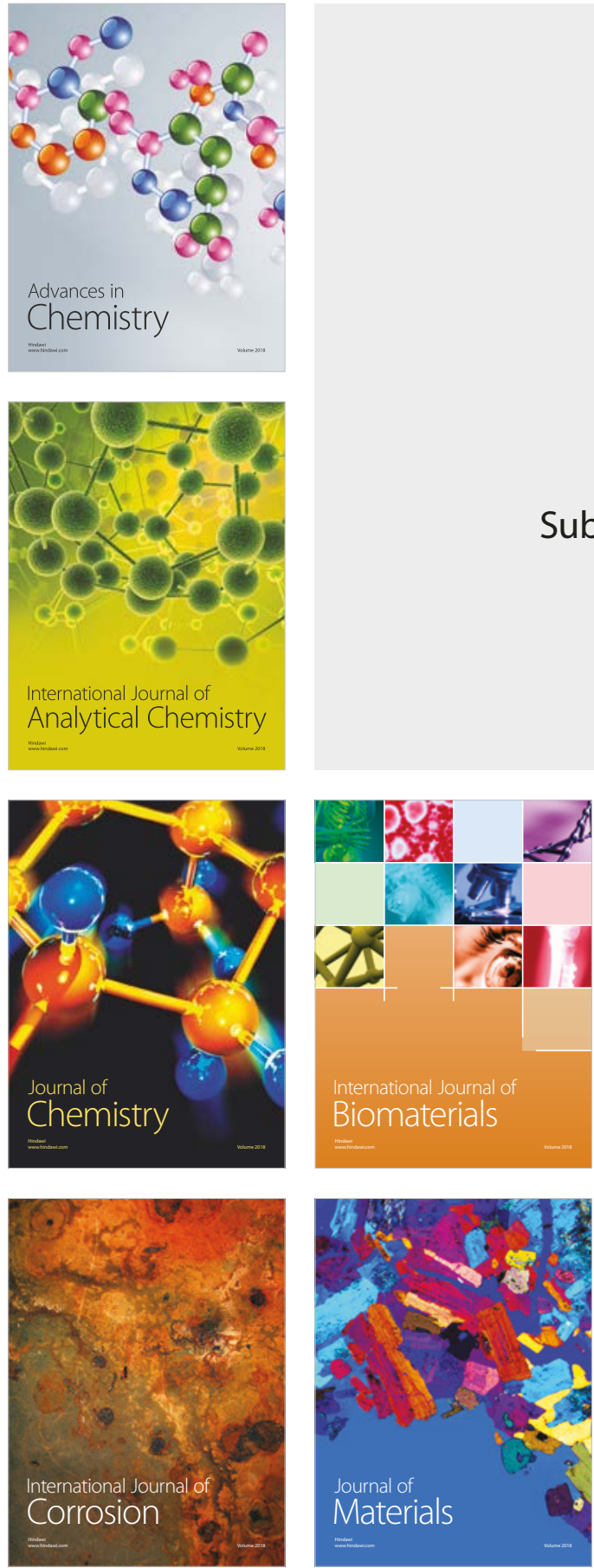

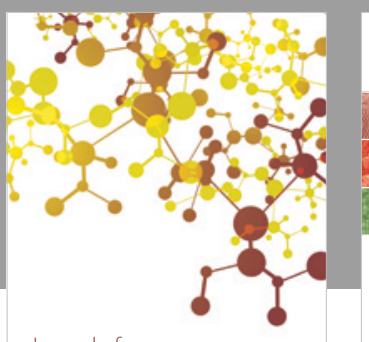

Journal of

Applied Chemistry
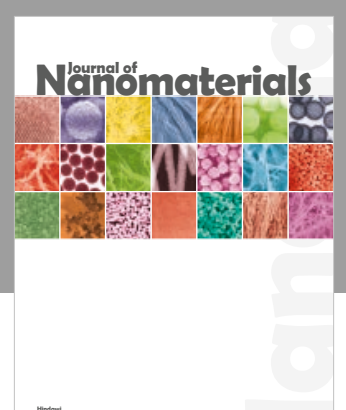

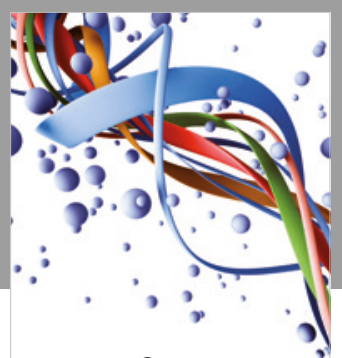

Scientifica

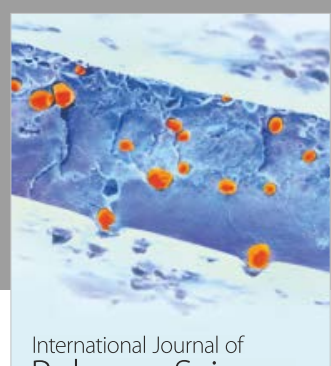

Polymer Science

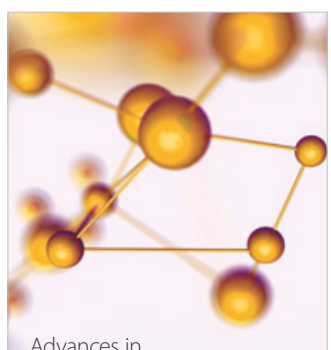

Physical Chemistry
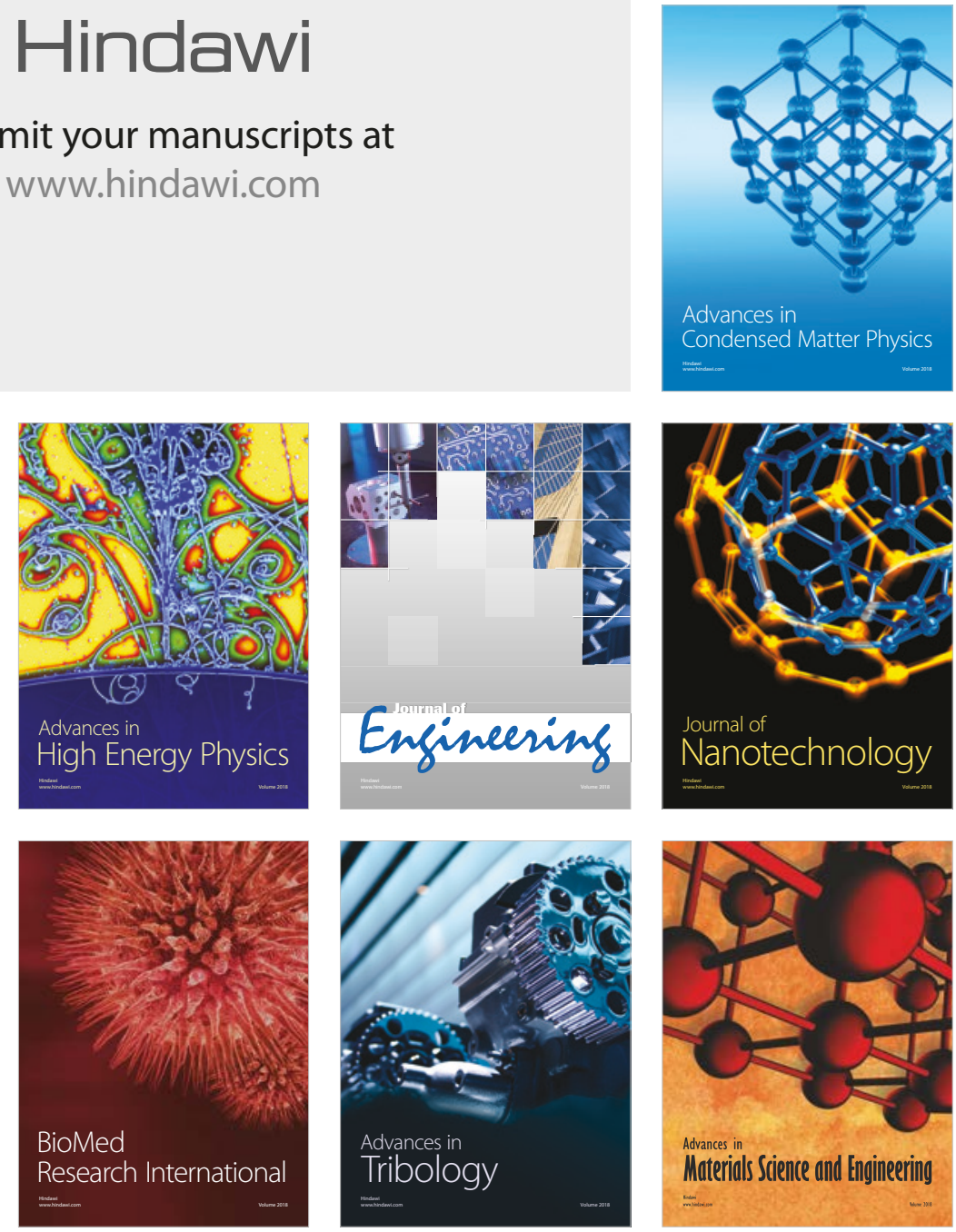